\title{
Amblyomma mixtum Koch, 1844 (Acari: Ixodidae): First record confirmation in Colombia using morphological and molecular analyses
}

\author{
Fredy A. Rivera-Páez ${ }^{\mathrm{a}, \mathrm{c}}$, Marcelo B. Labruna ${ }^{\mathrm{b}}$, Thiago F. Martins ${ }^{\mathrm{b}}$, \\ Bruno Rodrigues Sampieri ${ }^{a}$, Maria I. Camargo-Mathias ${ }^{\mathrm{a}, *}$ \\ a Departamento de Biologia, Instituto de Biociências, UNESP-Universidade Estadual Paulista, Avenida 24-A, 1515, Bairro Bela Vista, SP, Rio Claro CEP \\ 13506-900, Brazil \\ b Departamento de Medicina Veterinária Preventiva e Saúde Animal, Faculdade de Medicina Veterinária e Zootecnia, Universidade de São Paulo-USP, Av. \\ Prof. Orlando Marques de Paiva, 87, CEP 05508-000, Cidade Universitária, São Paulo, SP, Brazil \\ ${ }^{\mathrm{c}}$ Departamento de Ciencias Biológicas, Facultad de Ciencias Exactas y Naturales, Universidad de Caldas, Calle 65 No. 26-10 Apartado Aéreo 275 Manizales, \\ Caldas, Colombia
}

\section{A R T I C L E I N F O}

\section{Article history:}

Received 1 December 2015

Received in revised form 8 March 2016

Accepted 31 March 2016

Available online 1 April 2016

\section{Keywords:}

Amblyomma cajennense

Complex

Molecular markers

Rickettsia rickettsii

\begin{abstract}
A B S T R A C T
Up to some years ago, the taxon Amblyomma cajennense represented a single tick species in the New World, from southern United States to northern Argentina. Recent studies, based on genetic, reproductive and morphological data reorganized this taxon into a complex of the following 6 valid species: A. cajennense sensu stricto, Amblyomma mixtum, Amblyomma sculptum, Amblyomma interandinum, Amblyomma tonelliae, and Amblyomma patinoi. According to this classification, the A. cajennense complex is currently represented in Colombia by only one species, $A$. patinoi. Because the Colombian land is surrounded by confirmed records of A. mixtum in Panama and Ecuador, and by A. cajennense s.s. in Venezuela and the Brazilian Amazon, it is possible that these two species could also occur in Colombia. This study aimed to determine the occurrence of ticks of the A. cajennense complex in the Orinoquía region of Colombia. A total of 246 adult ticks of the Amblyomma genus were collected in three sampled regions: 71 females and 110 males in Arauca (Arauca Department), 27 females and 20 males in Nunchía (Casanare Department), and 10 females and 8 males in Yopal (Casanare Department). Based on morphological and molecular analyses, these ticks were identified as A. mixtum. Molecular analyses consisted of DNA sequences of two molecular markers, the nuclear second internal transcribed spacer (ITS2) and the mitochondrial cytochrome $c$ oxidase subunit I gene (COI). The presence of A. mixtum in Colombia is of medical relevance, since this species is incriminated as a vector of Rickettsia rickettsii in Central America.
\end{abstract}

(c) 2016 Published by Elsevier GmbH.

\section{Introduction}

Up to some years ago, the taxon Amblyomma cajennense represented a single tick species distributed in all tropical and subtropical areas of the New World, from southern United States to northern Argentina (Estrada-Peña et al., 2004). Recent studies, based on genetic, reproductive and morphological data reorganized this taxon into a complex of the following 6 valid species: A. cajennense sensu stricto (restricted to the Amazonian region), Amblyomma mixtum (from Texas to western Ecuador), Amblyomma sculptum (northern Argentina, Bolivia, Paraguay,

\footnotetext{
* Corresponding author.

E-mail address: micm@rc.unesp.br (M.I. Camargo-Mathias).
}

Brazil), Amblyomma interandinum (inter-Andean valley of Peru), Amblyomma tonelliae (dry areas of northern Argentina, Bolivia and Paraguay), and Amblyomma patinoi (Eastern Cordillera of Colombia) (Beati et al., 2013; Nava et al., 2014). According to this classification, the A. cajennense species complex is currently represented in Colombia by only one specie, A. patinoi (Nava et al., 2014). However, our current knowledge on the distribution of these species is probably incomplete, and examination of new field-collected material is required for a better definition of species boundaries (Nava et al., 2014). Moreover, A. cajennense s.l. constitutes the most important human-biting ticks of South America (Guglielmone et al., 2006), and at least three species of this species complex, namely A. sculptum, A. mixtum, and A. patinoi, are incriminated as important vectors of the bacterium Rickettsia rickettsii, the agent of the deadly Rocky Mountain spotted fever (Krawczak et al., 2014; Labruna et al., 2014; 
Faccini-Martínez et al., 2015). Therefore, a precise knowledge of the actual distribution of these species is of highly public relevance.

The six species of the A. cajennense species complex are morphologically very similar, making their morphological discrimination sometimes very difficult. The combination of morphological, distributional, and molecular information may sometimes be necessary for the correct determination of problematic specimens (Nava et al., 2014). While $A$. patino is the only member of this complex, precisely known to occur in Colombia (Nava et al., 2014; Faccini-Martínez et al., 2015), there have been multiple previous records of $A$. cajennense s.l. from different parts of Colombia (López-Valencia 1989; Estrada-Peña et al., 2004; Miranda et al., 2011). Unfortunately, these specimens are not available for morphological reexamination or molecular analysis. In addition, because the Colombian land is surrounded by confirmed records of A. mixtum in Panama and Ecuador, and by A. cajennense s.s. in Venezuela and the Brazilian Amazon (Nava et al., 2014), it is possible that these two species could also occur in Colombia.

In view of the above and considering the medical and veterinary importance of $A$. cajennense s.l. in Latin America, associated to the lack of studies on this complex in the Colombian territory, this study aimed to determine the occurrence of ticks of the $A$. cajennense complex in the Orinoquía region of Colombia.

\section{Material and methods}

Ticks were collected directly from horses (Equus caballus), cattle (Bos taurus), and a capybara (Hydrochoerus hydrochaeris) from different geographical sites of the Orinoquía region (Eastern Plains) of Colombia. The ecosystems of the region are tropical savanna with gallery forests and wetlands along the rivers. Ticks were collected from the following specific sites: Department of Arauca, Arauca municipality $\left(06^{\circ} 55^{\prime} 43^{\prime \prime} \mathrm{N}, \quad 70^{\circ} 27^{\prime} 36^{\prime \prime} \mathrm{W} / 06^{\circ} 02^{\prime} 0^{\prime \prime} \mathrm{N}, \quad 69^{\circ} 25^{\prime} 0^{\prime \prime} \mathrm{W} / 06^{\circ} 56^{\prime} 24^{\prime \prime} \mathrm{N}\right.$, $\left.70^{\circ} 32^{\prime} 0^{\prime \prime} \mathrm{W} / 07^{\circ} 1^{\prime} 48^{\prime \prime} \mathrm{N}, \quad 70^{\circ} 43^{\prime} 39^{\prime \prime} \mathrm{W} / 07^{\circ} 3^{\prime} 55^{\prime \prime} \mathrm{N}, \quad 70^{\circ} 44^{\prime} 2^{\prime \prime} \mathrm{W}\right)$ in September 2014; Department of Casanare, Nunchía municipality $\left(5^{\circ} 21^{\prime \prime} 1 " \mathrm{~N}, \quad 72^{\circ} 4^{\prime} 53^{\prime \prime} \mathrm{W} / 5^{\circ} 21^{\prime} 13^{\prime \prime} \mathrm{N}, \quad 72^{\circ} 5^{\prime} 50^{\prime \prime} \mathrm{W} / 5^{\circ} 21^{\prime} 40^{\prime \prime} \mathrm{N}\right.$, $\left.72^{\circ} 6^{\prime} 7^{\prime \prime} \mathrm{W}\right)$ and Yopal municipality $\left(5^{\circ} 19^{\prime} 27^{\prime \prime} \mathrm{N}\right.$, $\left.72^{\circ} 24^{\prime} 31^{\prime \prime} \mathrm{W} / 5^{\circ} 25^{\prime} 26^{\prime \prime} \mathrm{N}, 72^{\circ} 14^{\prime} 17^{\prime \prime} \mathrm{W}\right)$ in February 2015 . Collected ticks were submitted to taxonomic identification based on their external morphology following Jones et al. (1972) and Nava et al. (2014) through light microscopy (Leica M205C stereomicroscope). In addition, 2 male and 2 female specimens from each municipality (Arauca, Yopal and Nunchía) were prepared for scanning electron microscopy (SEM) (Hitachi Scanning Electron
Microscope, model TM3000) following techniques described by Corwin et al. (1979).

After morphological identification, 2 male and 2 female specimens of each Department were individually processed for molecular analyses. For this purpose, DNA was extracted using a DNeasy Blood \& Tissue Kit (Qiagen) following manufacturerís protocol, and tested by two PCR protocols, one targeting the ribosomal second internal transcribed spacer (ITS2) region, and the second one targeting the mitochondrial cytochrome c oxidase subunit I gene (COI). For the ITS2 PCR, we used primers ITS2 (F) 5'-CCATCGATGTGAAYTGCAGGACA-3' (Zahler et al., 1995) and MCLN (R) 5'-GTGAATTCTATGCTTAAATTCAGGGGGT-3' (Mclain et al., 1995), which correspond to the 5.8S and 28S regions, respectively, thus amplifying a DNA fragment that contains the complete sequence of the ITS2 of the rDNA, which has $\approx 1000$-bp in ticks of the genus Amblyomma (Marrelli et al., 2007). For the COI PCR, we used primers LCO1490 (F) 5'-GGTCAACAAATCATAAAGATATTGG-3' and HCO2198 (R) 5'-TAAACTTCAGGGTGACCAAAAAATCA-3', which amplify a $\approx 700$-bp fragment (Folmer et al., 1994). PCR products were purified using Wizard ${ }^{\circledR}$ SV Gel and PCR Clean-Up System Kit (Promega), according to the manufacturer's instructions, and sent to Macrogen Advancing Through Genomics (South Korea) for DNA sequencing.

DNA sequences were submitted to phylogenetic analyses. For this purpose, the quality analysis of the DNA sequences was performed with the Geneious Trial v8.14 software (Drummond et al., 2009). Sequence alignments were conducted with the ClustalW software (Thompson et al., 1997), included in the Mega 6 software (Tamura et al., 2013). Species identification and confirmation conducted through similarity estimation between sequences obtained from specimens collected in Colombia, in addition to representative sequences of six species of the A. cajennense complex derived from GenBank (Beati et al., 2013; Nava et al., 2014). Regarding the COI gene, the studied sequences had their similarities estimated through public sequences from GenBank and Barcode of Life Data Systems (BOLD-<www.barcodinglife.com>), registered as $A$. cajennense s.l. Variation of DNA sequences was estimated using the Kimura 2 parameter-K2 P (Kimura, 1980). A tree was created for o method (Neighbor-Joining-NJ) with 1000 replications in the bootstrap test. The K2 P parameter was selected as the genetic distance model in the Mega 6 software (Tamura et al., 2013).

The localities of the ticks collected in this study were plotted in a map, together with previously published records of A. patinoi, A. mixtum and A. cajennense s.s. by Nava et al. (2014), using the Geographic Coordinate System (WGS 1984, Datum: DWGS 1984) and the ESRI ${ }^{\circledR}$ ArcMap.

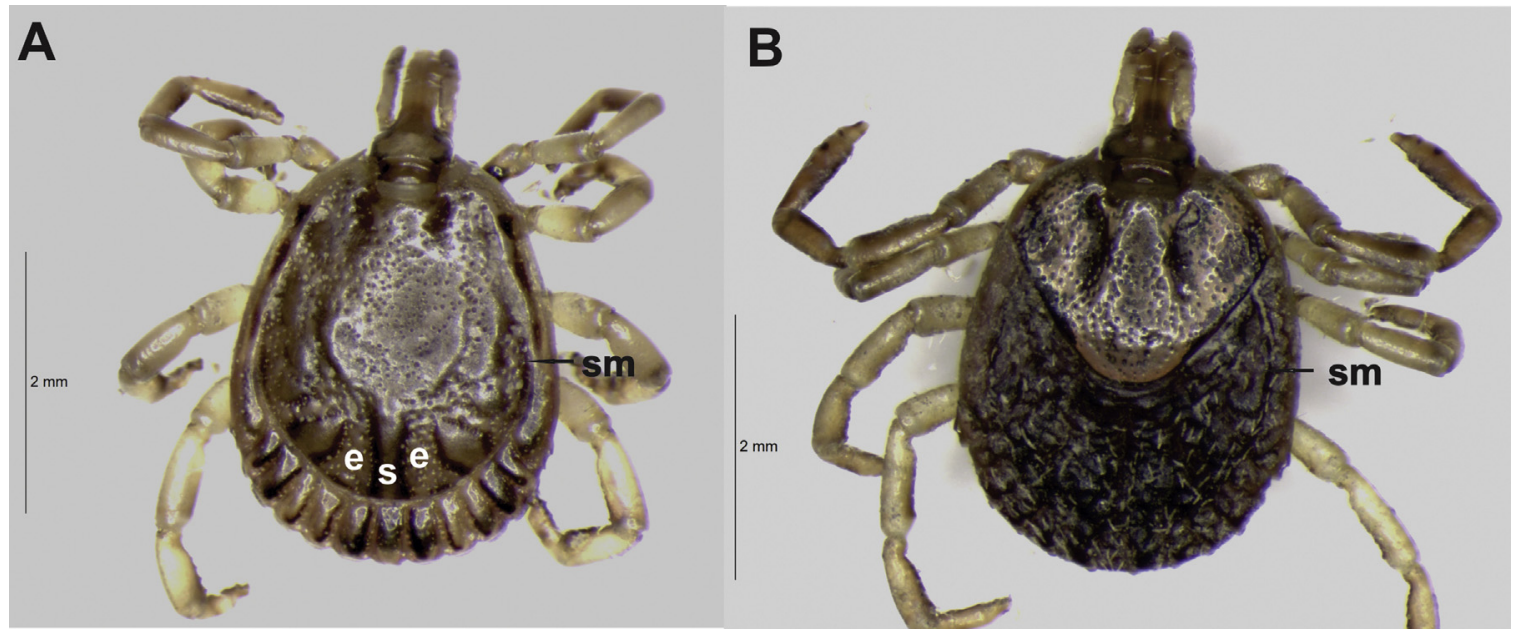

Fig. 1. Dorsal view of Amblyomma mixtum. (A) Male; (B) Female. (e) adjacent enamelled stripe, (s) postero-median spot, (sm) marginal groove. 

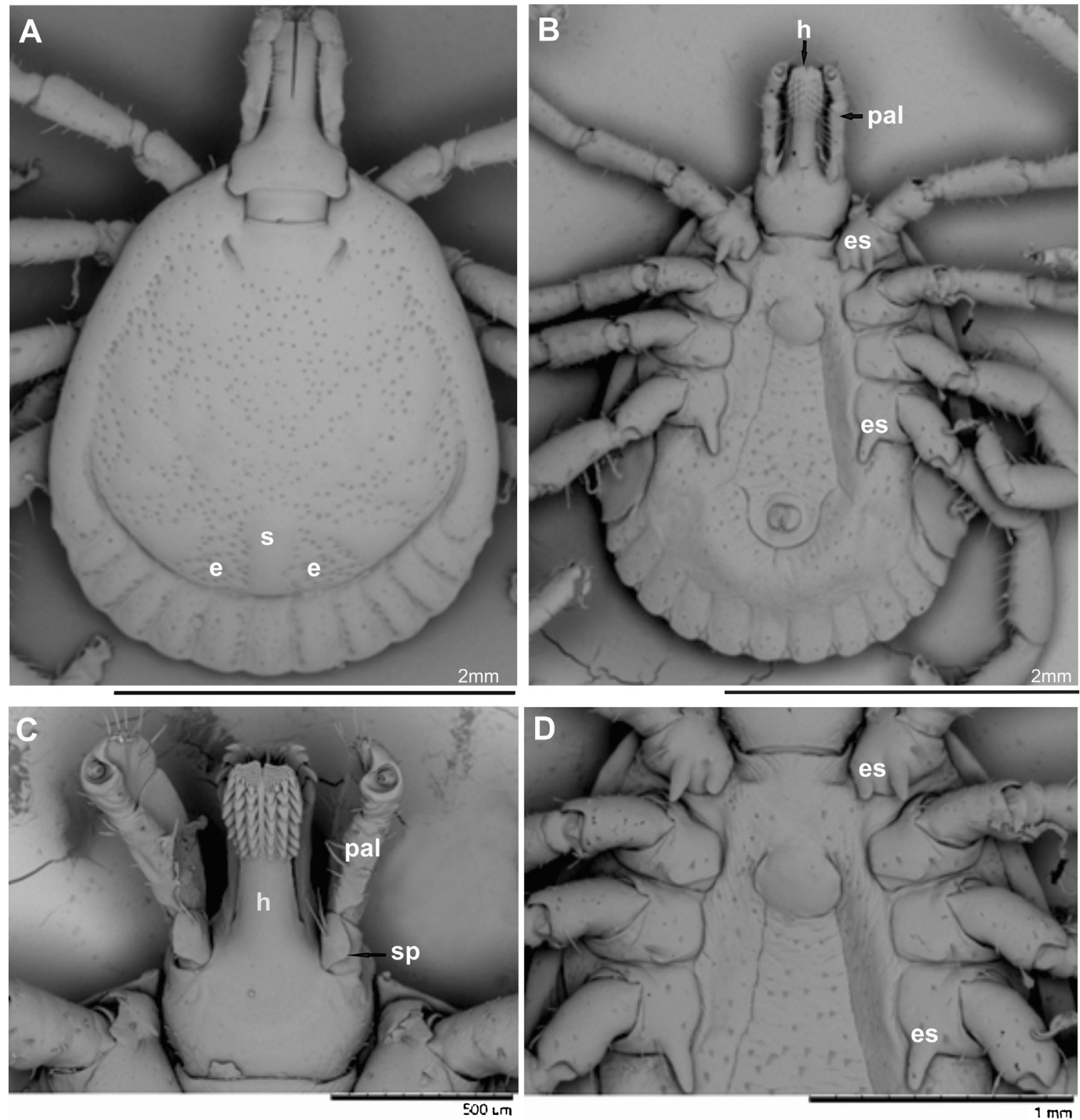

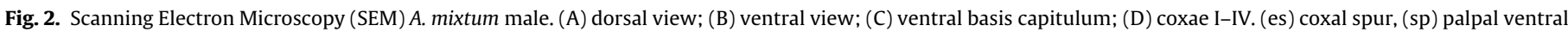
prolongation, (h) hypostome, (pal) palps, (e) adjacent enamelled stripe, (s) postero-median spot.

\section{Results}

A total of 246 adult ticks of the genus Amblyomma were collected in three sampled regions: 71 females and 110 males in Arauca, 27 females and 20 males in Nunchía, and 10 females and 8 males in Yopal. Initially, all ticks were morphologically identified as A. cajennense s.l. (Figs. 1-3). According to Nava et al. (2014), very few external morphological characters could be consistently used to separate species of the A. cajennense complex. One of these characters are the female genital opening, which is "V" shaped in A. cajennense s.s., A. tonelliae and A. interandinum, "U" shaped in A. sculptum and A. mixtum, and with short and bulging lateral flaps in A. patinoi. All female specimens of the present study presented an "U" shaped genital opening (Fig. 3D). According to Nava et al. (2014), morphological separation of males A. sculptum from A. mixtum are easily differentiable by the ornamentation and punctuations of the scutum, and in this case, geographical location should be applied, since the former species seems to be restricted to parts of South America south to the Amazon basin, whereas the later species occurs in regions north of the Amazon basin, from northern South America to southern Texas. Because the Orinoquía region of Colombia is located northern to the Amazon, we supposed that our specimens could be $A$. mixtum.

Attempts to conclusive taxonomic identification were performed through molecular analyses. In this case, fragments of the ITS2 gene were generated for 4 tick specimens of each Department. These sequences were aligned (832-bp) with representative sequences of the six species of the $A$. cajennense complex, in addition to $A$. americanum (outgroup), derived from GenBank. Phylogenetic analysis indicated that the Colombian specimens correspond to A. mixtum (Fig. 4). Similarly, fragments of the COI gene were generated from 4 tick specimens of each Department. These sequences were aligned (616-bp) with six sequences from GenBank and Barcode of Life Data Systems (BOLD) of A. cajennense s.l. and one of $A$. americanum (outgroup). The Colombian specimens 

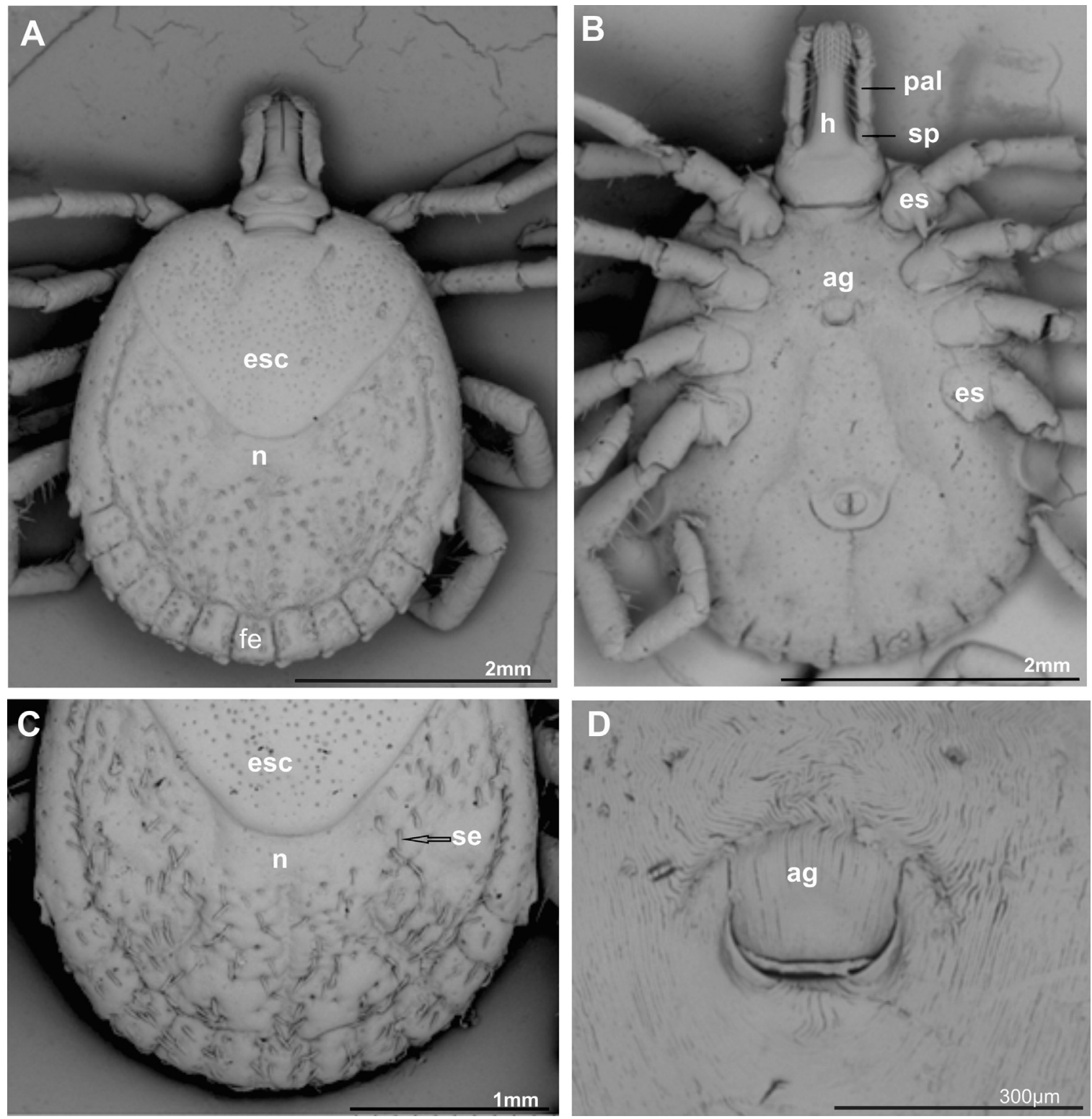

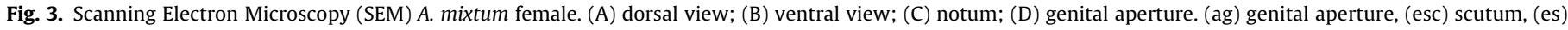
coxal spur, (sp) palpal ventral prolongation, (fe) festoons, (h) hypostome, (n) notum, (pal) palps, (se) setae.

clustered with sequences from Panama (Fig. 5), which correspond to the geographic area of $A$. mixtum according to Nava et al. (2014).

The intraspecific genetic distances between the ITS2 rDNA sequences of $A$. mixtum collected in Arauca and Casanare, in Colombia, and the sequences from GenBank of $A$. mixtum from Mexico, Costa Rica, and Texas revealed $0.5 \%$ maximum difference and $0.0 \%$ minimum. On the other hand, interspecific differences among the six $A$. cajennense complex-species ranged from 0.9 to $8.3 \%$ (Table 1). Regarding the COI sequences, the minimal difference between the Colombian species occurred with an A. cajennense s.l. sequence from Panama (Table 2), an area with known occurrence of A. mixtum, according to Nava et al. (2014).

\section{Discussion}

Morphological and molecular analyses of field-collected specimens of $A$. cajennense s.l. in the present study clearly confirm the occurrence of A. mixtum in Colombia for the first time. Genetic differences between the ITS2 and COI sequences of Colombian and
A. mixtum sequences from GenBank are in agreement with Beati et al. (2013), who performed an extensive genetic analysis of all six species of the A. cajennense complex. Because there have been previous records of $A$. mixtum in two neighboring countries of Colombia (Panama and Ecuador), ours findings are also corroborated by geographical data, especially because there is apparently no great eco-regional differences between the Orinoquía region of Colombia and other known A. mixtum areas (Estrada-Peña et al., 2014). On the other hand, Estrada-Peña et al. (2014) suggested that the Orinoquía region could be an area of sympatry or parapatry between $A$. mixtum and $A$. cajennense s.s. While we did not find any $A$. cajennense s.s. in the present study, we are aware that our convenient tick sample is not representative for the region (Fig. 6). Therefore, further studies are needed to better evaluate the possible occurrence of more species of the A. cajennense complex in the Orinoquía region of Colombia.

The presence of $A$. mixtum in Colombia is of medical relevance, since this specie is incriminated as the vector of $R$. rickettsii in Central America (Labruna et al., 2014). On the other hand, there has 


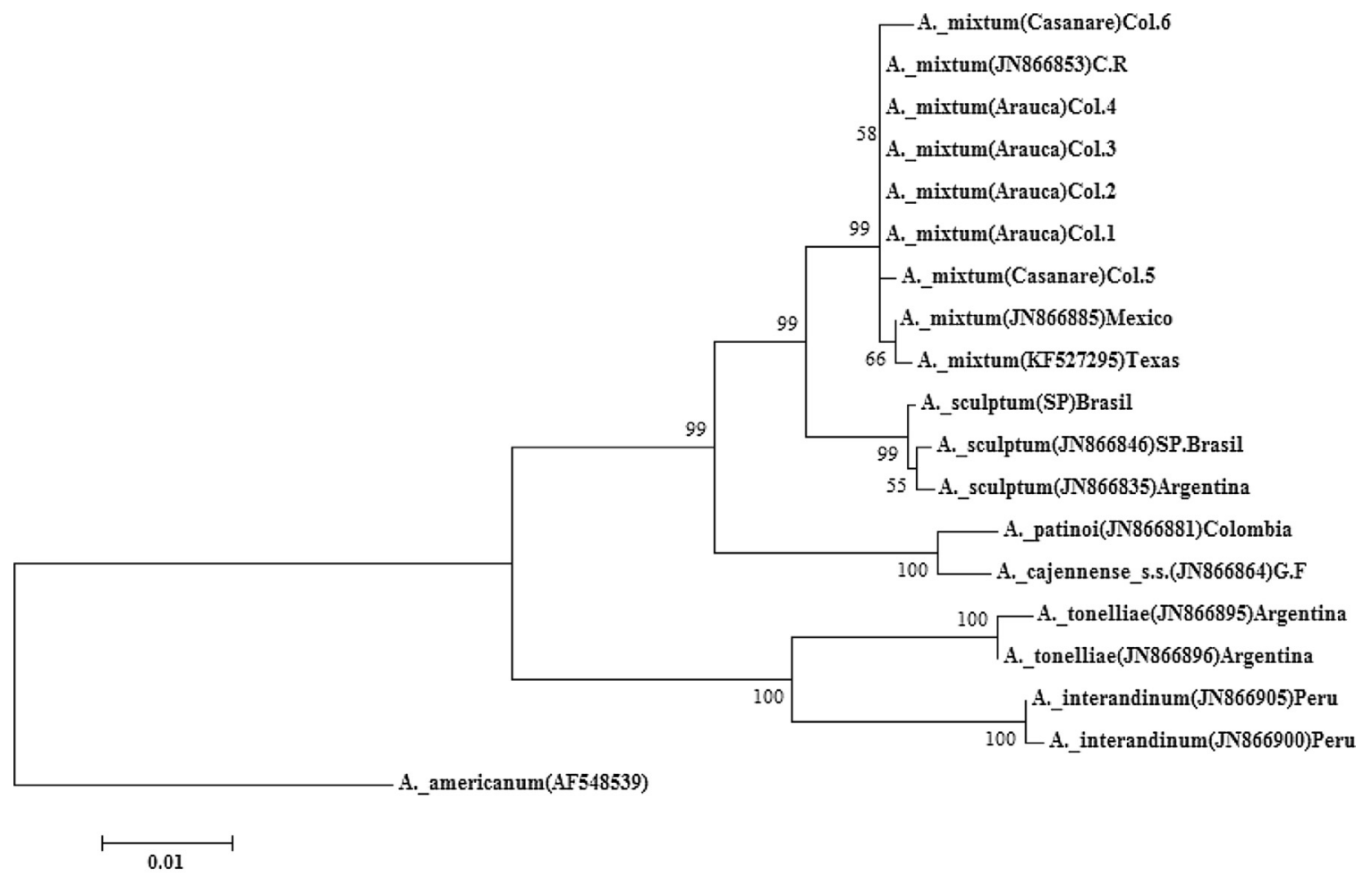

Fig. 4. Neighbor-joining tree using the sequences of the ITS2 rDNA gene.

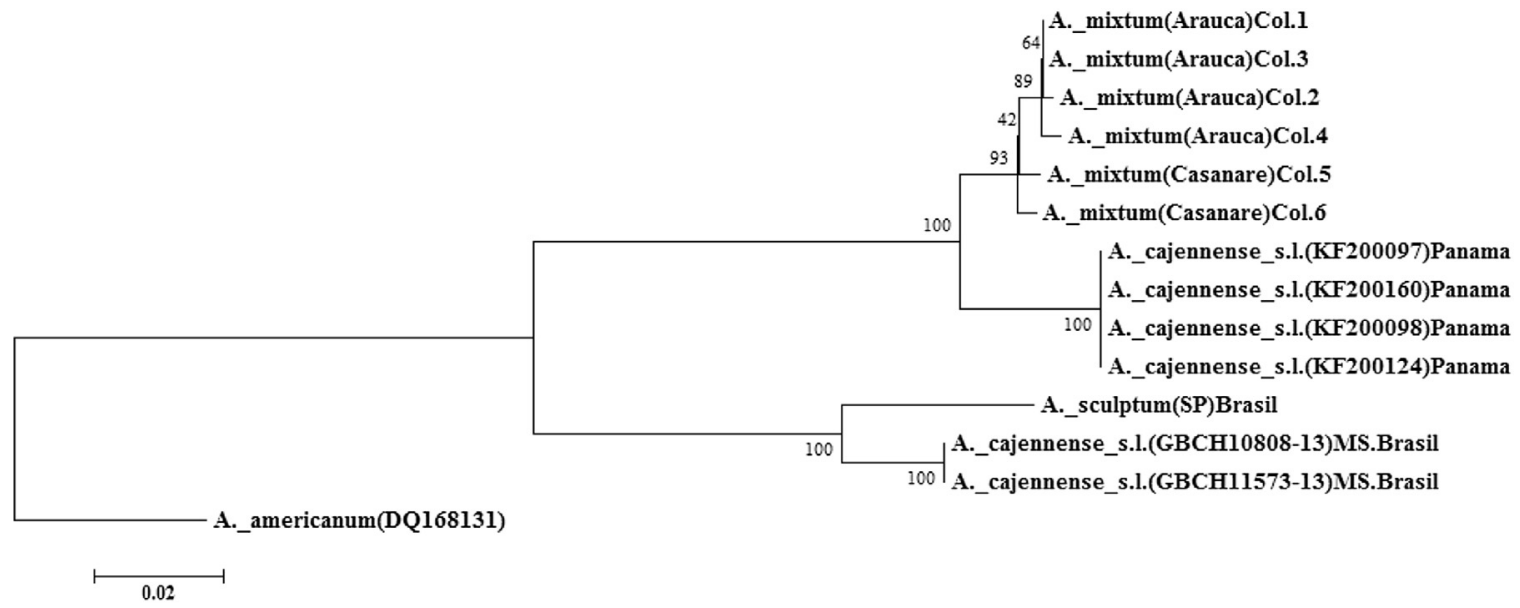

Fig. 5. Neighbor-joining tree using the sequences of the mitochondrial cytochrome c oxidase subunit I gene (COI).

Table 1

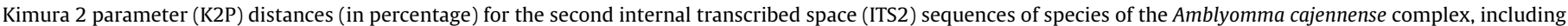
the A. mixtum sequences generated from ticks collected in Colombia in the present study.

\begin{tabular}{|c|c|c|c|c|c|c|c|c|}
\hline Tick species & A. mixtum & A. mixtum (Colombia) & A. sculptum & A. patinoi & A. cajennense & A. tonelliae & A. interandinum & A. americanum \\
\hline A. mixtum & $0.1-0.3$ & & & & & & & \\
\hline A. mixtum (Colombia) & $0.0-0.5$ & $0.0-0.4$ & & & & & & \\
\hline A. sculptum & $1.4-1.8$ & $1.4-1.8$ & $0.1-0.4$ & & & & & \\
\hline A. patinoi & $3.5-3.8$ & $3.5-3.8$ & $3.8-3.9$ & - & & & & \\
\hline A. cajennense & $3.4-3.6$ & $3.4-3.6$ & $3.6-3.8$ & 0.9 & - & & & \\
\hline A. tonelliae & $6.5-6.9$ & $6.6-7.2$ & $6.6-7.0$ & $7.7-8.0$ & $7.9-8.2$ & 0.3 & & \\
\hline A.interandinum & $6.8-7.2$ & $6.8-7.2$ & $7.0-7.3$ & $8.0-8.2$ & $8.2-8.3$ & $3.4-3.8$ & 0.1 & \\
\hline A. americanum & $9.6-9.9$ & $9.6-9.9$ & $10.0-10.1$ & 9.7 & 10.4 & $10.7-11.0$ & $10.4-10.6$ & - \\
\hline
\end{tabular}

been several records A. mixtum infection by Rickettsia amblyommii, a possible non-human pathogen or an agent of a much milder infectious disease (Bermúdez et al., 2009; Hun et al., 2011; Novakova et al., 2015). Previous studies in Panama and Brazil have reported that natural $R$. rickettsii-infection rates in A. cajennense s.l. ticks are usually very low (usually $\leq 1 \%$ ) (Sangioni et al., 2005; Krawczak et al., 2014). On the other hand, reported rates for $R$. amblyommiiinfected A. cajennense s.l. ticks are commonly >25\% (Bermúdez et al., 
Table 2

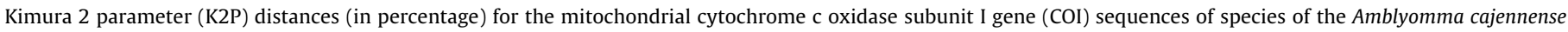
complex, including the A. mixtum sequences generated from ticks collected in Colombia in the present study.

\begin{tabular}{|c|c|c|c|c|c|}
\hline Tick species & A. mixtum (Colombia) & A. sculptumBrazil & A. cajennense. s.l. (Panamá) & A. cajennense s.l. Brazil & A. americanum \\
\hline A. mixtum (Colombia) & $0.2-1.0$ & & & & \\
\hline A. sculptum Brazil & $15.6-16.0$ & - & & & \\
\hline A. cajennense s.l. (Panamá) & $3.2-3.8$ & 16.2 & 0.0 & & \\
\hline A. cajennense s.l. (Brazil) & $14.5-14.7$ & 4.5 & 14.3 & 0.0 & \\
\hline A. americanum & $18.4-18.9$ & 18.2 & 20.2 & 17.8 & - \\
\hline
\end{tabular}

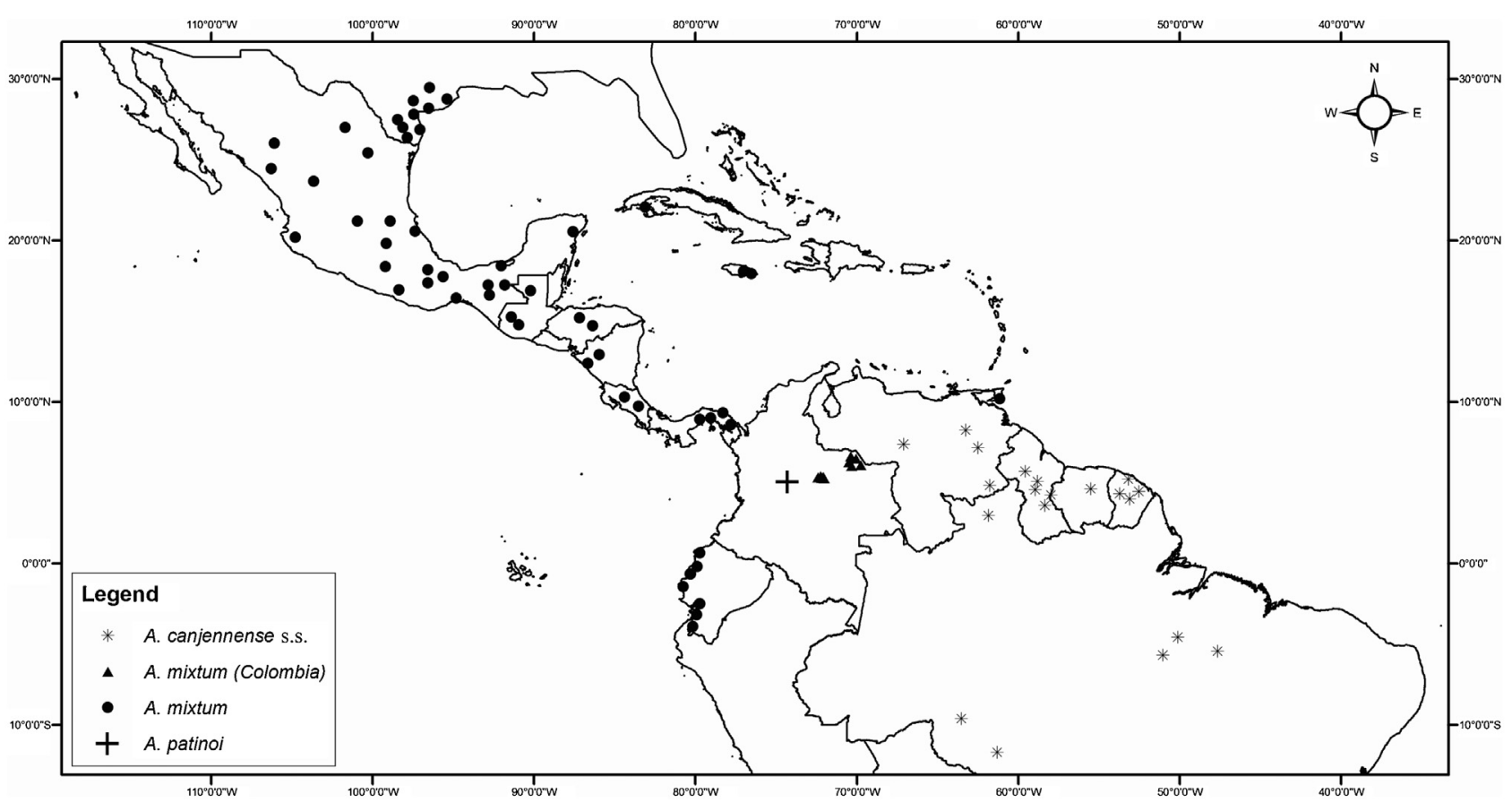

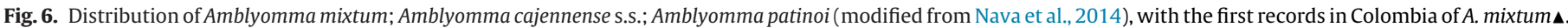

2009; Labruna et al., 2004; Soares et al., 2015). Because laboratory studies have suggested that previous infection by $R$. amblyommii could prevent a severe disease during a subsequent infection by the highly pathogenic $R$. rickettsii (Blanton et al., 2014; Rivas et al., 2015), it is possible that previous human contact with A. mixtum ticks could decrease potentially fatal spotted fevers, yet to be reported from the study area.

\section{Acknowledgements}

AUIP-Asociación Universitaria Iberoamericana de Postgrado. CNPq-Conselho Nacional de Desenvolvimento Científico e Tecnológico. Unidad Administrativa Especial de Salud de Arauca Programa ETV Gobernación de Arauca (Colombia).

\section{References}

Beati, L., Nava, S., Burkman, E.J., Barros-Battesti, D., Labruna, M.B., Guglielmone, A.A., Cáceres, A.G., Guzmán-Cornejo, C., Léon, R., Durden, A.L., Faccini, J.L., 2013. Amblyomma cajennense (Fabricius, 1787) (Acari: Ixodidae), the cayenne tick: phylogeography and evidence for allopatric speciation. BMC Evol. Biol. 13, 267.

Bermúdez, S.E., Eremeeva, M.E., Karpathy, S.E., Samudio, F., Zambrano, M.L., Zaldivar, Y., Motta, J.A., Dasch, G.A., 2009. Detection and identification of rickettsial agents in ticks from domestic mammals in eastern Panama. J. Med. Entomol. 46, 856-861.

Blanton, L.S., Mendell, N.L., Walker, D.H., Bouyer, D.H., 2014. Rickettsia amblyommii induces cross protection against lethal Rocky Mountain spotted fever in a guinea pig model. Vector Borne Zoonotic Dis. 14 (8), 557-562.

Corwin, D., Clifford, C.M., Keirans, J.E., 1979. An improved method for cleaning and preparing ticks for examination with the scanning electron microscope. J. Med. Entomol. 16, 352-353.
Drummond, A.J., Ashton, B., Cheung, M., Heled, J., Kearse, M., Moir, R., Stones, H.S. Thierer, T., Wilson, A., 2009. Geneious 8 (14) (disponible en:) http://www. geneious.com

Estrada-Peña, A., Guglielmone, A.A., Mangold, A.J., 2004. The distribution and eco-logical preferences of the tick Amblyomma cajennense (Acari: ixodidae), an ectoparasite of humans and other mammals in the Americas. Ann. Trop. Med. Parasitol. 98, 283-292.

Estrada-Peña, A., Tarragona, E.L., Vesco, U., Meneghi, D., Mastropaolo, M., Mangold, A.J., Guglielmone, A.A., Nava, S., 2014. Divergent environmental preferences and areas of sympatry of tick species in the Amblyomma cajennense complex (Ixodidae). Int. J. Parasitol. 44, 1081-1089.

Faccini-Martínez, Á.A., Costa, F.B., Hayama-Ueno, T.E., Ramírez-Hernández, A Cortés-Vecino, J.A., Labruna, M.B., Hidalgo, M., 2015. Rickettsia rickettsii in Amblyomma patinoi ticks, Colombia. Emerg. Infect. Dis. 21 (3), 537-539.

Folmer, O., Black, M., Hoeh, W., Lutz, R., Vrijenhoek, R., 1994. DNA primers for amplification of mitochondrial cytochrome c oxidase subunit I from diverse metazoan invertebrates. Mol. Mar. Biol. Biotechnol. 3, 294-299.

Guglielmone, A.A., Beati, L., Barros-Battesti, D.M., Labruna, M.B., Nava, S., Venzal, J.M., Mangold, A.J., Szabó, M.J.P., Martins, J.R., González Acuña, D. Estrada-Peña, A., 2006. Ticks (Ixodidae) on humans in South America. Exp. Appl. Acarol. 40, 83-100.

Hun, L., Troyo, A., Taylor, L., Barbieri, A.M., Labruna, M.B., 2011. First report of the isolation and molecular characterization of Rickettsia amblyommii and Rickettsia felis in Central America. Vector Borne Zoonotic Dis. 11 (10), 1395-1397.

Jones, E.K., Clifford, C.M., Keirans, J.E., Kohls, G.M., 1972. The ticks of Venezuela (Acarina: Ixodoidea) with a key to the species of Amblyomma in the western hemisfere. Brigham Young Univ. Sci. Bull. Biol. Ser. 17, 1-40.

Kimura, M., 1980. A simple method for estimating evolutionary rate of base substitutions through comparative studies of nucleotide sequences. J. Mol. Evol. 16, 111-120.

Krawczak, F.S., Nieri-Bastos, F.A., Nunes, F.P., Soares, J.F., Moraes-Filho, J., Labruna, M.B., 2014. Rickettsial infection in Amblyomma cajennense ticks and capybaras (Hydrochoerus hydrochaeris) in a Brazilian spotted fever-endemic area. Parasite Vectors 5, 7-7.

López-Valencia, G., 1989. Biología y distribución de garrapatas en Colombia: control de garrapatas. Rev. Inst. Colomb. Agropecu 39, 33-45. 
Labruna, M.B., Whitworth, T., Bouyer, D.H., McBride, J.W., Camargo, L.M.A., Camargo, E.P., Popov, V., Walker, D.H., 2004. Rickettsia bellii and Rickettsia amblyommii in Amblyomma ticks from the state of Rondonia, Western Amazon, Brazil. J. Med. Entomol, 41, 1073-1081.

Labruna, M.B., Santos, F.C., Ogrzewalska, M., Nascimento, E.M., Colombo, S., Marcili, A., Angerami, R.N., 2014. Genetic identification of rickettsial isolates from fatal cases of Brazilian spotted fever and comparison with Rickettsia rickettsii isolates from the American continents. J. Clin. Microbiol. 52 (10), 3788-3791.

Marrelli, M.T., Souza, L.F., Marques, R.C., Labruna, M.B., Matioli, S.R., Tonon, A.P., Ribolla, P.E., Marinotti, O., Schumaker, T.T., 2007. Taxonomic and phylogenetic relationships between neotropical species of ticks from genus Amblyomma (Acari: ixodidae) inferred from second internal transcribed spacer sequences of rDNA. J. Med. Entomol. 44, 222-228.

Mclain, D.K., Wesson, D.M., Oliver, J.H., Collins, F.H., 1995. Variation in ribosomal DNA internal transcribed spaces 1 among eastern populations of Ixodes scapularis (Acari: Ixodidae). J. Med. Entomol. 32, 353-360.

Miranda, J., Contreras, V., Negrete, Y., Labruna, M.B., Máttar, S., 2011. Vigilancia de la infección por Rickettsia sp: en capibaras (Hydrochoerus hydrochaeris) un modelo potencial de alerta epidemiológica en zonas endémicas. Biomédica 31 (2), 216-221.

Nava, S., Beati, L., Labruna, M.B., Cáceres, A.G., Mangold, A.J., Guglielmone, A.A., 2014. Reassessment of the taxonomic status of Amblyomma cajennense (Fabricius, 1787) with the description of three new species, Amblyomma tonelliae n. sp., Amblyomma interandinum n. sp. and Amblyomma patinoi n. sp., and reinstatement of Amblyomma mixtum Koch, 1844, and Amblyomma sculptum Berlese, (Ixodida: Ixodidae). Ticks Tick Borne Dis. 5, 252-276.
Novakova, M., Literak, I., Chevez, L., Martins, T.F., Ogrzewalska, M., Labruna, M.B., 2015. Rickettsial infections in ticks from reptiles, birds and humans in Honduras. Ticks Tick Borne Dis. 6 (6), 737-742.

Rivas, J.J., Moreira-Soto, A., Alvarado, G., Taylor, L., Calderón-Arguedas, O., Hun, L., Corrales-Aguilar, E., Morales, J.A., Troyo, A., 2015. Pathogenic potential of a Costa Rican strain of 'Candidatus Rickettsia amblyommii' in guinea pigs (Cavia porcellus) and protective immunity against Rickettsia rickettsii. Ticks Tick Borne Dis. 6 (6), 805-811.

Sangioni, L.A., Horta, M.C., Vianna, M.C.B., Gennari, S.M., Soares, R.M., Galvão M.A.M., Schumaker, T.T.S., Ferreira, F., Vidotto, O., Labruna, M.B., 2005.

Rickettsial infection in animals and Brazilian spotted fever endemicity. Emerg. Infect. Dis. 11, 265-270.

Soares, H.S., Barbieri, A.R., Martins, T.F., Minervino, A.H., De Lima, J.T., Marcili, A., Gennari, S.M., Labruna, M.B., 2015. Ticks and rickettsial infection in the wildlife of two regions of the Brazilian Amazon. Exp. Appl. Acarol. 65 (1), 125-140.

Tamura, K., Stecher, G., Peterson, D., Filipski, A., Kumar, S., 2013. MEGA 6: molecular evolutionary genetics analysis version 6.0. Mol. Biol. Evol. 30, 2725-2729.

Thompson, J.D., Gibson, T.J., Plewniak, F., Jeanmougin, F., Higgins, D.G., 1997. The CLUSTAL X windows interface: flexible strategies for multiple sequence alignment aided by quality analysis tools. Nucleic Acids Res. 25, 4876-4882.

Zahler, M., Gothe, R., Rinder, H., 1995. Genetic evidence against a morphologically suggestive conspecificity of Dermacentor reticulatus and D. marginatus (Acari: ixodidae). Int. J. Parasitol. 25, 1413-1419. 